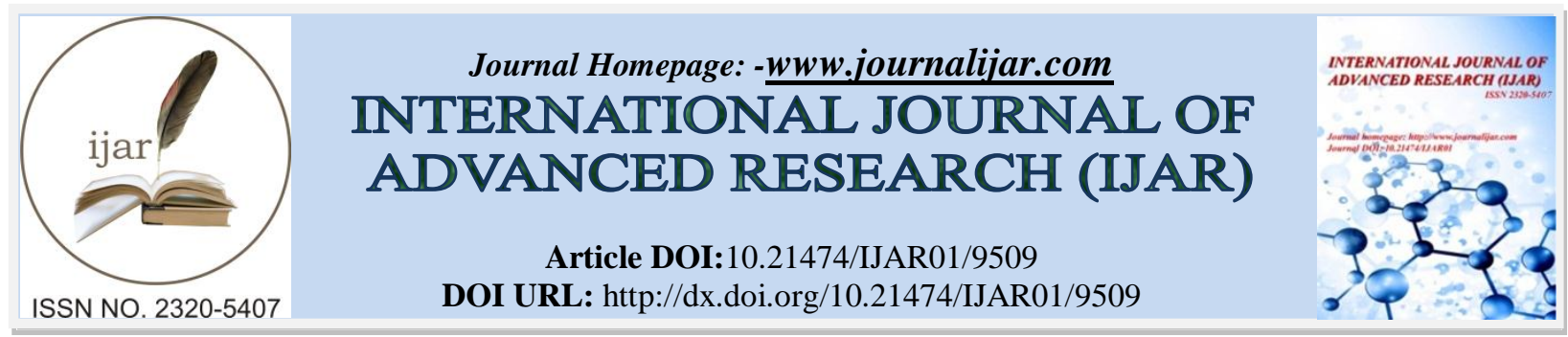

RESEARCH ARTICLE

\title{
PIONEERS OF REPERTORY THEATRES.
}

\author{
Dr. Pradnya S. Yenkar. \\ Associate Professor, Department of English,Vidyabharati Mahavidyalaya, AMRAVATI (MS)-444602.INDIA.
}

\section{Manuscript Info}

Manuscript History

Received: 06 June 2019

Final Accepted: 08 July 2019

Published: August 2019

\section{Abstract}

The staging of Shakespeare's plays was revolutionized by GranvilleBarker's productions at the Savoy Theatre, which were admired for their simplicity, fluidity, and speed. Equally significant for the British theatre was the founding of the first provincial repertory theatre in 1908 by Horniman at the Gaiety, Manchester. It not only provided opportunities for promising British playwrights but also presented works by important Continental dramatists. Mainstream British theatre paid very little attention to the antirealistic movements that characterized experimental theatre in the rest of Europe. The domination of the actor-manager was effectively challenged by Harley Granville-Barker and John E. Vedrenne at London's Royal Court Theatre; between 1904 and 1907 they staged numerous new plays by British and Continental writers. The major dramatist at the Royal Court, indeed the most important British dramatist of the century, was the Irish-born George Bernard Shaw. The Irish theatre movement and the repertory theatres in England brought about that decentralization of the drama which became the most important development in English theatrical history since the sixteenth century.In Great Britain the name repertory theatre came to designate an important movement, begun in the early 1900s, to make quality theatre available throughout the country.Repertory in its true form has existed in state-supported theatres in France, Germany, and elsewhere; but, as it is rather expensive and difficult to maintain, most modern repertory companies used a modification of the system, usually presenting fewer and longerrunning plays, alternately or successively, in one season. Repertory theatre has proved effective in supporting both commercially successful and experimental drama. It has served as a showcase for the early work of playwrights such as Eugene O'Neill and John Millington Synge and as a training ground for young actors. It is a popular format for summer festivals as well as national theatres.

The present paper discusses the evolution of repertory theatre, causes of the repertory movement and evolution of repertory theatre. It also discusses the role and the contribution made by the pioneers of the repertory theatre. 


\section{Introduction:-}

The repertory theatre movement was forged out of the passion and conviction of two individuals, Barry Jackson and Annie Horniman who believed that a wide variety of theatrical experience should be made available to people at a price they could afford. Horniman believed that by subsidizing theatres you could both raise the standards of performance and broaden the programme a theatre could offer to its community. As a method of theatre organisation, repertory refers to those theatres based primarily in the regions, housing a resident acting company and seeking to maintain each season a programme of plays catering for the tastes of the whole community. But the theory has never been dogmatic and the movement has evolved from a gamut of complex factors, not least the visions of particular personalities. The acting company would usually consist of a leading lady, a leading man, a set of juveniles (one male and one female ingénue for the young often romantic role(s)), a character actor and actress (for the older or eccentric parts) and perhaps a vain and girlish soubrette. The company might occasionally bring in a guest star to increase interest, albeit in exchange for a cost increase often large enough to offset the rise in revenues brought by any increase in attendance. The resident cast would number seven, plus the resident director, usually serving as the artistic director in charge of the whole enterprise. Additionally there would be the stage director, the assistant stage manager (ASM), some unpaid apprentices, and light and sound technicians. Newcomers to the profession would often start their careers in this fashion, and members would gain a foundation upon which to base their future careers. Paid members could also be sure of a steady income for one or more seasons, which might last for six months. Examples of performers who went on to universal recognition are Errol Flynn, John Gielgud, Ralph Richardson, Laurence Olivier, Jeremy Brett, Judi Dench, Rosemary Harris, Ian McKellen, Peter O'Toole, Christopher Plummer, Harold Pinter, Imelda Staunton, Lynn Redgrave, Arthur Lowe, Vanessa Redgrave, Patrick Stewart, Geraldine McEwan and Ronnie Barker. Dirk Bogarde wrote about his start at tiny Amersham rep in 1939, and Michael Caine has recounted his time spent at Horsham rep in the early fifties.

\section{London Monopoly and Evolution of Repertory Movement:}

Major landmarks in the history include the effects of the two World Wars, the advent of substantial state funding for the Arts, the growth of cinema and television and the renewal of theatre's link with the community in the form of such initiatives as Theatre- in-Education. From the time of Shakespeare onward, 'English drama' meant, almost entirely, the plays produced in the London theatres. Dramatists had come to accept the London monopoly as one of the natural conditions of their craft, and grew accustomed to working within the limits imposed by that monopoly. The theatre was a place existing mainly for one of two purposes: (a) the exploitation of the personality of an actormanager; (b) the provision of financial profit for a commercial manager who 'kept' a theatre as other men might keep a butcher-shop. The first confident challenge to the London monopoly came from the Irish theatre in Dublin; but meanwhile, in London itself, there had been the beginnings of revolt. J. T. Grein's Independent Theatre experiment introduced Bernard Shaw as a dramatist, and there were other sporadic efforts of a similar kind in the middle of the 'nineties. The repertory movement was not only an attempt to free the theatre from the dictatorship of the financier and the actor-manager; it was also inspired by definite theories of dramatic art. (i)The 'long-run' system was regarded as injurious to both the play and the players, since it led to a mechanical style of acting that deadened the mind of the player and made him a machine instead of a sensitive instrument; the result being a coarsened interpretation of the play. The repertory system was based upon the team principle. (ii)There were no permanent 'stars' among the actors: the Hamlet of one performance might be a second murderer in the next. (iii)Under the old system, theatre managers 'called in' scene-painters, costumiers, composers, lighting experts, and others, to carry out certain separated pieces of work. The repertory system created a corporate art of the theatre, an organic whole, not a casual assemblage of disunited parts. (iv)Most important of all for dramatic literature was the fact that repertory directors recognized that a good play might attract only comparatively small audiences. Under former conditions such a play had practically no chance of production, since little, if any, profit could be expected from it. But in the repertory theatres a few performances of a play with a limited appeal were balanced financially by the production of plays of a more popular type.

\section{Miss A. E. F. Horniman: Mother of Early Twentieth-Century English Drama:}

One name stands out from the list of pioneers-Annie Elizabeth Fredericka Horniman born at Surrey Mount, Forest Hill, London, in 1860, was an English theatre patron and manager. The mother of early twentieth-century English drama, Miss Horniman, studied art under Professor Legros at the Slade School, and horrified her Victorian parents by interesting herself in woman's suffrage and in theatrical affairs. Her father was opposed to the theatre, which he considered sinful, but their German governess took Annie and Emslie secretly to a performance of 'The Merchant of Venice' at The Crystal Palace when Annie was aged 14. ${ }^{1}$ Annie's father allowed her to enter the Slade School of Fine Art in 1882. Here she discovered that her talent in art was limited but she developed other interests, particularly 
in the theatre and opera. She took great pleasure in Wagner's Ring cycle and in Ibsen's plays. She cycled in London and twice over the Alps, smoked in public and explored alternative religions ${ }^{2}$. The "lonely rich girl" had become "an independent-minded woman". In 1890 she joined the occult society, the Hermetic Order of the Golden Dawn, where she remained a member until disagreements with its leaders led to her resignation in 1903. Annie's first venture into the theatre was in 1894 was made possible by a legacy from her grandfather.In 1894 she provided money for a season at the Avenue Theatre, London, which helped forward the Ibsen-Shaw movement. She anonymously supported her friend Florence Farr in a season of new plays at the Avenue Theatre, London. This included a new play by Yeats, The Land of Heart's Desire, and the première of George Bernard Shaw's play Arms and the Man. In 1903 Yeats persuaded her to go to Dublin to back productions by the Irish National Theatre Society. Here she discovered her skill as a theatre administrator. She bought a property and developed it into the Abbey Theatre, which opened in December 1904. Although she moved back to live in England she continued to support the theatre financially until 1910. Meanwhile, she had purchased and renovated the Gaiety Theatre in 1908 and developed it into the first regional modern repertory theatre in Great Britain at the Midland Theatre, Manchester.For over next twelve years 'Miss Horniman's Company' set a standard for the rest of the theatrical world.

At the Gaiety she appointed Ben Iden Payne as the director and employed actors on 40-week contracts, alternating their work between large and small parts. The plays produced included classics such as Euripides and Shakespeare, and she introduced works by contemporary playwrights such as Ibsen and Shaw. She also encouraged local writers who formed what was known as the Manchester School of dramatists, the leading members of which were Harold Brighouse, Stanley Houghton and Allan Monkhouse. The Gaiety Company undertook tours of America and Canada in 1912 and 1913. Annie became a well-known public figure in Manchester, lecturing on subjects which included women's suffrage and her views about the theatre. In 1910 she was awarded the honorary degree of MA by Manchester University. During the First World War the Gaiety continued to stage plays but financial difficulties led to the disbandment of the permanent company in 1917, following which productions in the theatre were by visiting companies. In 1921 Annie sold the theatre to a cinema company. By that time, however, Miss Horniman's work had had substantial and lasting results elsewhere. Other provincial towns had instituted successful repertory theatres. Sybil Thorndike and Lewis Casson, having done excellent work at the Manchester Gaiety, helped Lilian Baylis to give London a permanent Shakespeare theatre at the Old Vic in Waterloo Bridge Road; after which, on their own account, they proceeded to popularize Greek tragedy throughout the country in the intervals of much other work. When she retired in 1921, the Manchester Gaiety fell from grace and became a cinema. She died in 1937 at her home in Shere, Surrey.

\section{Court Theater and Vedrenne-Barker programme:}

The most successful repertory experiment in London was that conducted at the Court Theatre from 1904 to 1907 by J. E. Vedrenne and Granville Barker: Vedrenne as the man of affairs, Barker the man of the theatre. During that Court season thirty-two plays (new and old, native and foreign) were staged. The outstanding feature was the unanticipated popularity of Bernard Shaw. Eleven of his plays were produced, and these accounted for 701 performances out of a total of 988 during the season. The Vedrenne-Barker programme included, also, plays by Granville Barker himself (The Voysey Inheritance), John Galsworthy (The Silver Box), Ibsen, Euripides (in Gilbert Murray's translations), Maeterlinck, John Masefield, St John Hankin, and others. Much that is best in contemporary drama came from the Court Theatre season. ${ }^{3}$

Granville Barker (1877-1946) producer, director, playwright, actor and polemicist during the Court Theatre season, was born in London and at the age of thirteen was sent to the Theatre Royal, Margate, at that time a combination of stock company and dramatic school. Harley Granville-Barker brought Shakespeare into the 20th century. We automatically associate the Royal Court Theatre in Sloane Square with George Devine's English Stage Company and the explosive impact of John Osborne's Look Back in Anger. But 50 years earlier, at the same London address and with similar ideals, Barker had launched three revolutionary seasons (1904-07) that fought to create the conditions in which intelligent new drama could flourish, challenging the pernicious system of long runs, lavish settings, and an emphasis on stars that deterred artistic risk. Almost 1,000 performances were presented, of 32 plays by 17 authors, including Ibsen, Galsworthy, Yeats, Maeterlinck, and, above all, Shaw. The repertory movement and the National Theatre for which Barker agitated (drawing up the first detailed Scheme for it in 1907, with the critic William Archer) owe a huge amount to his example and inspiration, as does modern Shakespeare production. In his landmark 1912 stagings of 'The Winter's Tale and Twelfth Night', Barker used an apron stage, a full text rather than a slashed and bowdlerised one, and non-realistic backdrops, while promoting rapid verse delivery ("Character in action, not sound like the voice beautiful from a lectern...") and fluency of action. In 1891, he made his first 
appearance on the London stage, under Charles Hawtrey, and afterwards acted in Ben Greet's and William Poel's Shakespearian companies. He also appeared in Shaw plays, and served as producer to the Stage Society. By the time he began work at the Court Theatre, therefore, Barker was a fully qualified man of the theatre. In a later venture (at the Savoy, 1912) he produced three Shakespearian plays in an original manner. Though A Winter's Tale and A Midsummer Night's Dream were perhaps unduly strange and fantastic, Twelfth Night was a triumph. The costumes and stage setting were new in style, unobtrusive but sufficient. They were a pleasant 'point of rest' for the eyes of the audience, whose minds were left free to take in the sense and enchanting music of Shakespeare's poetry. Though the work of a stage producer cannot be preserved and immortalized, it is not the least of Granville Barker's achievements that he enabled some thousands of his contemporaries to hear, for the first time, Shakespeare as he should be heard. These performances were taken at a pace about one-third faster than had been customary on the modern stage.For a short time it seemed that he might become the leading dramatist of his generation. The Marrying of Ann Leete (1899), his first play, appeared before the influence of the Russian dramatist Tchehov had reached England, yet it is probably the most Tchehovianplay in English. The censoring of Waste (1907) brought Granville Barker into public notice, but The Voysey Inheritance (1905) was his finest achievement. This is one of the best and richest plays of modern times. It lacks the moral and intellectual fervour of Bernard Shaw, but in almost every other respect 'The Voysey Inheritance' displays that joy of creation and superabundant vitality lacking from a great deal of contemporary drama. Granville Barker's people in this play are well nourished at the feast of life; by their side, some of Galsworthy's later characters seem like dyspeptic ghosts gathered around a board of funeral baked meats. Galsworthy had, however, what Barker evidently had not namely, sustained power of creation. Apart from translations (e.g. of Spanish plays by Sierra and the Quintero brothers) Granville Barker wrote only two long plays between 1907 and 1925: The Madras House (1911) and The Secret Life (1923). In neither of these did he equal 'The Voysey Inheritance', although the first act of The Madras House is excellent.

\section{Rise of Stanley Houghton:}

By 1912 there was a 'Manchester school' of dramatists known on two continents. The leading playwrights of the Manchester group were Allan Monk-house, Harold Brighouse, and Stanley Houghton. Stanley Houghton (18811913) A British playwright, born in Cheshire and educated at Manchester Grammar School, was a Manchester business man with an active interest in the theatre. Between 1905 and 1912 he wrote dramatic criticism for Manchester newspapers, and in 1908 his one-act play 'The Dear Departed' was accepted for Miss Horniman's company. With this and other pieces he gained local fame, but in 1912 he found himself suddenly and unexpectedly with a London reputation. Miss Horniman had been invited by the Stage Society to give a performance in London, and she chose 'Hindle Wakes' by Stanley Houghton for that occasion. The play, which had not previously been performed, was received with enthusiasm by critics and audiences alike, and Stanley Houghton was 'made'. 'Hindle Wakes' is a lively comedy on Houghton's favourite theme, the right to personal freedom of the young, here represented by the weaver who appals the older generation by choosing independence rather than marriage to the mill owner's son who has made her pregnant. Houghton is clearly attacking 'double standards' of morality and showing the little town of Hindle, in the words of the ambiguous title, 'waking' to the twentieth century; he achieves this through humorous observation of character and of Lancashire.

'Hindle Wakes' was put on for an extended season in London, and managers pursued the author. It is probable that London was attracted by the wrong things in Hindle Wakes. Metropolitan audiences detected a piquant flavour of sexual excitement in Fanny Hawthorn's refusal to marry the young man with whom she had enjoyed a week-end excursion at Llandudno. The true dramatic and literary interest lies mainly, however, in the skilful portraits of the old people of the two families. This is true also of 'The Younger Generation', with its terrifying Puritan grandmother whose religious philosophy can be summed up in her own words: 'There's original sin in every young man and young woman, and it's got to be stamped out of them. Yes, scourged out of them with whips, and burnt out of them with fire if need be.'

\section{A Repertory Dramatist John Drinkwater:}

After Dublin and Manchester, Birmingham produced a repertory dramatist of wide repute. John Drinkwater (18821937) a prolific poet, dramatist, critic, and actor born in Leytonstone, the son of a schoolteacher, when still a teenager, he began work as an insurance man, and it was while working in Birmingham that he became involved in the literary and theatrical worlds.He was a successful promoter of repertory theatre in England and the author of popular chronicle dramas.His work appeared in all five volumes of Georgian Poetry, and was collected in 1933 in Summer Harvest. He wrote many plays, including Abraham Lincoln (1918), Oliver Cromwell (1921), Mary Stuart (1922), and a successful comedy Bird in Hand (1927). By 1913 he was both a published poet and a manager of the 
Birmingham Repertory Theatre; his 'Abraham Lincoln' was produced. This play, with its idealistic central figure and noble aspirations, came as a tonic to many people distressed by the war of 1914-18 and its brutalities, its threats of reprisals and counter-reprisals. Written at any other time its success with the public might have been no greater than that of Drink-water's later historical plays (Cromwell, Mary Stuart, and Robert E. Lee). It is, however, a more impressive play than these: a skilful adaptation of biography and history to the conditions of the modern theatre. It is impressive without pretentiousness or grandiloquence; and by the careful selection and utilization of significant detail, (like the passage about Lincoln's disreputable hat in Scene I), Drink-water created a convincing and admirable personality.

Of great importance in the development of Drinkwater's career as a dramatist was his friendship with Barry Jackson, whom he met in 1904, and his experience as an actor and playwright for Jackson's Pilgrim Players, the group that evolved into the influential Birmingham Repertory Theatre. His association with Jackson and his early stage experience are best detailed in the second volume of his autobiography, Discovery (I932). Although the verse plays he wrote for the Birmingham Repertory Theatre between 1914 and 1917 gained him some degree of deserved recognition, it was his Abraham Lincoln (1918) that alone won him international fame and guaranteed him a large and continued audience for all his work. By attracting large audiences for a long period, Abraham Lincoln demonstrated that the spoken word (without rhodomontade and without the aid of extravagant action) can be made to appeal to a large popular audience. That was a point worth demonstrating in a time (before broadcasting) when the silent film was threatening the spoken drama. Abraham Lincoln went far also towards fulfilling a prophecy made by John Galsworthy nearly ten years previously. The plane of exaltation required in poeticdrama is reached more frequently in the prose passages of Abraham Lincoln than in the blank verse of Stephen Phillips. Yet, for the time being, Abraham Lincoln was to remain a solitary pointer, and when a general stirring of interest in poetic drama came about it was on the very different model of Auden and Isherwood and their circle, followed by the more acclaimed T. S. Eliot and Christopher Fry. Most critics now would agree with Robert Spiller's assessment that Drinkwater's innovations have not contributed greatly to modern dramatic technique. His feel for the elements of successful stage production, perhaps resulting from his long practical stage experience, seems to have been great; even reviewers who have questioned the value of a particular play as a piece of dramatic literature often have praised the production of the play for its acting and overall impact.

\section{Conclusion:-}

The repertory movement in Britain played an important role for local writers and as a training ground for actors to experiment and expand their repertoire. Under the repertory theatre system, drama flourished in the English provinces as it had not done since the days of the medieval craft guilds and their cycles of religious plays, with numerous successful dramatic enterprises in the larger towns, and, also, amateur groups working with skill and enthusiasm all over the country in villages, towns, and cities, in Scotland and Wales as well as in England. Drawbacks to the repertoire system are increased production costs as each show will need separate sets, props, costumes and actors, (although sometimes an actor will be engaged to play in more than one production). Many such companies are large, and are able to have a smaller space available to workshop an experimental production or present play readings. But the standard should be higher than under the old-time repertory system, because there will be more time for rehearsal. Also, many repertoire companies today have non-profit status, so that budgets and income should be higher because they will not just depend upon ticket sales. However, the downside is that promotional costs will also be much higher, due to having to employ a separate staff.Granville Barker, Known as a pioneer of the National Theatre and Repertory Movement, and remembered mainly for his Prefaces to Shakespeare, from the 1900s to his death in the 1940s Granville Barker commented enthusiastically in newspaper items, introductions to plays, articles, essays, articles, and published lectures on a range of topics: the nature of theatre as an art form and as a social medium, the need for ensemble playing in a repertory system, the relationship between the three chief constituents of theatre - the actor, the playwright and the audience.

\section{References:-}

1. Cheeseman, Peter (2004), "Horniman, Annie Elizabeth Fredericka (1880-1937)", Oxford Dictionary of National Biography

2. 2"The Annie Horniman Papers", London Metropolitan University, archived from the original on 5 February 2012

3. Desmond MacCarthy (1907) "The Court Theatre:1904-07".

4. Chambers, Colin (2002) “Continuum Companion to Twentieth Century Theatre”. London: Continuum 
5. Stanton, Sarah; Banham, Martin (1996). "The Cambridge Paperback Guide to Theatre". Cambridge: Cambridge University Press

6. George Rowell, Anthony Jackson(1984), "The Repertory Movement: A History of Regional Theatre in Britain"University of Manchester. 